\title{
GOVERNANCE AND DEVELOPMENT: THE VIEWS FROM WASHINGTON
}

Carol Lancaster

Journalists and public policy analysts often talk about the 'view from Washington' or the 'Washington consensus' when referring to the current development policies of the Bretton Woods institutions - the World Bank and the International Monetary Fund - and the United States government. While these institutions at times share the same views on development policies, this is not the case with 'governance' and development. The Bretton Woods institutions and the US Government have in recent years taken high profile positions on the need for better governance in developing countries. But the logic, the politics and the policy implications of the positions of these institutions are different. This article will explore their differences as well as the ethical, technical and practical issues raised by their emphasis on governance in economic development, with special reference to Africa, where in the words of the World Bank, there has been a 'crisis of governance'.

\section{THE WORLD BANK AND GOVERNANCE}

In its 1989 study, Sub-Saharan Africa: From Crisis to Sustainable Growth, the World Bank first pointed to the importance of governance in economic development. The Bank's concerns about governance arose from one major source: the failure of its structural adjustment programmes to produce a definitive success on the African mainland. Structural adjustment programmes typically involve a variety of economic reforms in monetary, fiscal, trade, regulatory policies and public sector management. These reform programmes have been based on the assumption that, if sufficient economic incentives are provided to producers, they will expand existing production and invest in new productive activities, thus providing the engine for sustained economic growth. What has, in fact, happened in the most successful of Africa's adjustment experiments - for example, in Ghana - is that, after nearly a decade of economic reform backed by large inflows of foreign aid, agricultural production has expanded, exports have increased, and growth rates have risen. But significant private investment has not occurred. Indeed, there has been a considerable amount of disinvestment as firms have closed down in a more competitive environment or have been unable to obtain adequate credit to finance their operations. The same can be said of Nigeria where the private sector response to economic reforms has been insignificant. Economic growth has been buoyed by an increased use of existing capacities and foreign aid. Without the anticipated growth in private investment, capacity limitations will become constraining and growth will remain dependent on aid flows. Why, World Bank staff asked, has the new investment not appeared?

The answer they came up with was 'poor governance' After some groping, the Bank settled on the following definition of governance: 'the manner in which power is exercised in the management of a country's economic and social resources for development' ${ }^{1}$ Discussions of governance by the World Bank of ten include several specific problems: lack of accountability, transparency, and predictability on the part of politicians and bureaucrats and the absence of the rule of law. (These terms are of ten used as proxies for a less polite term corruption - one of the Bank's central concerns in the area of governance, especially in Africa.) Bank staff view these problems in particular as having discouraged private investors from risking their capital in the uncertain and unpredictable political environments of Africa. Even in countries where economic reforms have been extensive, investors remain unsure how long the new policies will last (especially where elections are pending), whether their property will be protected by the law and the courts, and whether corruption which has been so widespread will not in the end consume their profits. As a result of these problems, it is argued, anticipated investment has not appeared and 'governance' must improve before it does. Good governance, in the Bank's view, has become a means to the end of sustained economic growth in the developing world and above all, in Africa.

While few would dissent from the proposition that good governance is an important ingredient of development, several difficult issues are raised by the Bank's approach to governance. First is the definition itself. The breadth and vagueness of the definition the management of social and economic resources for development - provides few clues for the analyst or practitioner as to the nature of governance or the factors affecting its quality. The Bank goes on to describe the focus of its interest in terms that suggest it is concerned primarily with the familiar issues of public sector management, such as effective financial accounting and auditing, an appropriate legal frame-

World Bank, Governance and Development, Washington, DC, 1992: 1. 
work and open competition for public contracts. ${ }^{2}$ But judging from the thinking of senior Bank officers and from the Bank's activities in Africa at least, this focus underestimates the real scope of the Bank's interest in governance, a scope that extends by implication to political participation, to open political debate, and to establishment of political legitimacy.

One indication of the thinking of Bank staff regarding governance is reflected in a recent paper by Pierre Landell-Mills and Ismail Serageldin, in which they suggest that good governance should include a 'minimal core of characteristics which, if not universally accepted, are nonetheless widely agreed upon.' ${ }^{3}$ That core included accountability, transparency, establishment of the legitimacy of the government through a 'well defined open process of public choice such as elections, referendum, etc.', assurance of the safety and security of citizens, the rule of law, freedom of association and expression of opinions. ${ }^{4}$ Another Bank official in the Africa Region has predicted that research 'would underline the need to incorporate the political dimension in current structural reform programmes. There can be no sustainable long-term development without social justice and political stability." Finally, the former President of the World Bank, Barber Conable, warned the African Governors of the World Bank at their meeting with him in 1990:

Allow me to be blunt: the political uncertainty and arbitrariness evident in so many parts of subSaharan Africa are major constraints on the region's development ... I am not taking a political stance here, but I am advocating increased transparency and accountability in government, respect for human rights and adherence to the rule of law . . . Governance is linked to economic development, and donors are showing signs that they will no longer support systems that are inefficient and unresponsive to the people's basic needs.' 6

The implications of these statements are, of course, highly political. To establish transparency, governments must provide the public with information on their activities and the public must be able to evaluate that information. It is hard to see how this can occur without freedom of the media. And it is normally a very short step from freedom of the media to freedom of association, where citizens can meet and discuss their views and organize to promote them. Accountability implies that politicians can be penalized for foolish

2 The emphasis on public sector management was even more pronounced in the Bank's internal discussion paper on governance Managing Development: The Governance Dimension - written for the Bank's Board of Directors.

Pierre Landell-Mills and Ismael Serageldin, Governance and the External Factor, World Bank Annual Conference on Development Economics, Washington, DC, 1991: 6.

4 Ibid.: 6,7 . policies or corrupt behaviour. It is hard to see how politicians can be penalized short of losing their jobs in some form of election. It is difficult to see how the rule of law can be preserved without an independent judiciary. While Bank staff are careful not to identify specific political reforms they think Africans should adopt, and abjure simplistic solutions like 'multiparty democracy', the policy implications of their emphasis on transparency, accountability, the rule of law, political participation and legitimacy are not difficult to see.

The Bank's emphasis on governance has not only involved general statements. The need for political reforms has been a key element in Bank discussions with a number of African governments. For example, beginning in 1990, Bank officials began to press the governments of Kenya and Malawi to adopt political reforms aimed at seeking a 'broader political consensus' and improving public accountability and transparency within these countries. ${ }^{7}$ A year earlier, the Bank had suspended disbursements of its structural adjustment loan to strike-torn Benin, informing the government that it could not continue its disbursements until it had 'the consent of its people' to continue its reform programmes. (The Beninese government was broke and faced widespread strikes and demonstrations. The cutoff of Bank financing forced President Kerekou to take action to reduce the political turmoil in his country. He sought a national consensus on economic reforms through making concessions to demands for political liberalization. But he lost control of the process of political change. A 'national conference' of nearly 500 prominent Beninese met, declared itself 'sovereign', rewrote the country's constitution, elected an interim government and set dates for national elections. Kerekou reluctantly accepted these changes, contested the elections and lost. The 'national conference' was subsequently imitated in other Francophone African countries and contributed to the wave of political liberalization in the region which is still underway.)

Bank staff are careful in their formal exchanges with officials from borrowing governments not to put the Bank out front on these essentially political issues. It is usually possible to urge a borrowing government to adopt political reforms by referring to the discontent of bilateral aid donors with poor governance and warning that, without reforms, the Bank will be unable to encourage other aid donors to continue providing aid.

5 Dunstan, M. Wai, 'Governance, Economic Development and the role of External Actors', paper delivered at the Conference on 'Governance and Economic Development in sub-Saharan Africa', Queen Elizabeth House, Oxford University, May 1991: 15.

6 Cited in ibid.: 13.

7 The information in these paragraphs is based on extensive interviews with Bank staff and Africans. 
Then, in the event that other donors decided to terminate their aid, the Bank would find it difficult to continue its own lending operations.

In the past two years the Bank has extended the scope of its development concerns to include the political environment in borrowing countries. Its focus on the political environment has not been uniform everywhere. Bank staff need two conditions to address primarily political issues effectively: (a) the backing of major bilateral donors, whose discontent they can cite in raising political issues; and (b) a measure of desperation on the part of borrowing governments for Bank credits and Bank approbation. The latter is important if they are to obtain aid from other sources, or debt relief. While dissatisfaction on the part of bilateral aid donors with poor governance in a borrowing country is certainly important for the Bank in raising the need for political change with the borrower, what is not known is the extent to which the Bank, through its informal contacts with officials from bilateral donors, has actually raised their awareness of the problems of poor governance in a borrowing country, as opposed to simply acting as a messenger for those governments. Individuals or institutions acting as brokers can often have a major influence on the messages they transmit and the deals they facilitate.

However, there are limits on the Bank's ability to raise the governance issue directly with officials from borrowing governments. Where a poorly governed borrower has powerful foreign government patrons unconcerned with governance or where aid represents a small proportion of GNP and external debts are serviceable, the Bank may have considerable difficulties including issues of governance in its discussions. For example, there is little evidence that the issue of governance played a role in discussions between the Bank and the Cote d'Ivoire over the past year, even though the government jailed several prominent leaders of the political opposition, and corruption, by many accounts, remains a serious problem.

There are several problems with the extension of the Bank's scope of interest to include governance. Some commentators have raised the issue of 'sovereignty' that the Bank and other aid donors are intruding ever more deeply into questions which have traditionally remained the sole responsibility of individual governments. One may argue the philosophical and legal points raised by the impact on a country's sovereignty of international concerns about governance. But what seems increasingly clear in the 'new world order' is that the nature of a country's political regime will influence its relations with foreign governments. This is not a new development; but, with the end of the Cold War, it has become a far more prominent and explicit element in international relations. The Bank's fosus on governance is thus part of a much broader trend in which the concept of sovereignty appears rapidly to be changing.

The issue of sovereignty may be a red herring. But there are a number of other issues raised by the Bank's focus on governance that pose difficult practical problems. The first one stems from the difficult dilemma facing the Bank as it takes on the issue of governance. It is clear that the political environment in a borrowing country can play a major role in shaping the country's development and the economic effectiveness of Bank credits. Even prominent economists have recognized this fact $^{8}$ and it is only sensible that the institution takes it into account in its lending decisions. If it had been able and willing to do so in the past, it could have saved itself a great deal of wasted credits in Africa and elsewhere. However, what is not known and is far from clear in Bank discussions and documents is precisely what sorts of political problems are critical to the success of Bank lending and which ones are not. For example, experience in Africa and elsewhere demonstrates that absence of accountability and transparency do not automatically lead to corruption and the absence of the rule of law. They may raise the probability of corrupt practices but they do not make them inevitable or preclude effective government policies for economic development. South Korean development in the past has been led by authoritarian regimes, lacking both in transparency and accountability to their people and not without a measure of corruption. However, these problems of 'governance' did not impede rapid economic growth. On the other hand, democratic government does not ensure good governance, particularly in the economic sphere. The government of Gambia has long been democratic, with a free press, the right of assembly, the right to create political parties and periodic elections. It has also suffered from many of the same economic problems existing in the rest of sub-Saharan Africa, including poor economic management and extensive corruption. We know that good governance, especially in the economic sphere, is important to development. We cannot be so certain of the relationship between political systems and governance or political systems and development. Other factors, involving the quality of political leadership, external security threats, widely shared cultural norms, social structure, ideology, even the size and characteristics of foreign aid, can affect the quality of governance regardless of the nature of the
${ }^{8}$ Lloyd Reynolds, 'The Spread of Economic Growth to the Third World: 1850-1980', Fournal of Economic Literature, September, 1983, vol XXI: 976. The author ends his long essay with the following statement: ' $M y$ hypothesis is that the single most important explanatory variable is political organization and the administrative competence of government. At this point, as a properly modest economist, I disclaim further responsibility and pass the problem to my political science colleagues.' 
regime. Reality is considerably more complex than the Bank's approach to governance suggests and neither Bank staff nor development specialists yet have a firm understanding of these interrelationships.

But the other half of the Bank's dilemma prevents the institution from being honest with itself and others about the implications of 'governance' for its involvement in political issues in borrowing countries and from gaining the expertise to address those issues effectively: the Bank cannot openly admit the degree of its involvement in political issues without appearing to contravene the word and spirit of its articles of agreement which state that 'the Bank and its officers shall not interfere in the political affairs of any member; nor shall they be influenced in their decisions by the political character of the member or members concerned. ${ }^{9} \mathrm{On}$ the issue of governance, the Bank is in danger of acting without transparency or accountability.

The further potential problem relates to the nature of the Bank as a multilateral development institution. It does not have the ability to intervene in borrowing countries to ensure that the political reforms it urges governments to adopt do not lead to political instability or violence. The ways to avoid such problems might include identification of an alternative political leadership (where the existing one is incapable of governing well and where no organized opposition has been permitted), resolving conflicts among groups competing for power, strengthening political institutions and so on. Urging governments to liberalize politically is laudable from a human rights point of view and may make sense from an economic perspective. But what will be the consequences of pressures for political liberalization on societies? What is to stop an autocrat from provoking ethnic animosities to prove to the Bank and others that democracy will not work in his country? To urge political changes in complex societies, however morally justified those changes may be, on the basis of limited knowledge and without the ability to ensure that the changes are smooth and effective is a policy of power without responsibility.

\section{THE IMF AND GOVERNANCE}

While the World Bank has focused on governance, the International Monetary Fund's 'governance' issue has been excessive military spending in developing countries. As far as is known, the Fund has raised this problem only in the public statements of its Managing Director and other officials and in private discussions with borrowing governments; it has not yet included reducing military expenditures or downsizing the military as a condition of its lending. (World Bank staff have also begun raising this issue with their borrowers and have requested data on such expenditures as part of their public sector expenditure reviews.) It certainly appears to be the case that many developing country governments spend more on their military establishments than would seem justified by the security threats facing them, either internally or externally. Political leaders, in response to pressure from their own armed forces for salaries, prerequisites and expensive equipment or from foreign governments attempting to increase their exports through arms sales, often expand military budgets regardless of their security needs. And expenditures on military equipment and salaries absorb scarce monies that could be used to maintain social services or finance investment in times of fiscal austerity. The IMF's calling attention to this problem is useful. But should fire eventually break out where there is now smoke, with the Fund or Bank pressing borrowers hard or even tying lending to a reduction in military expenditures, there could be serious problems for borrowing governments. Reducing military expenditures, especially where those reductions involved sacking military officers or reducing their salaries, has in the past provoked coups. If reduced military expenditure is to become a criterion for lending in the future, either on the part of the Bank or the Fund, it is time now to begin exploring ways of avoiding a backlash on the part of the military when their budgets and employment are reduced.

\section{THE UNITED STATES GOVERNMENT AND GOVERNANCE}

For the Bretton Woods institutions, good governance is a means to the end of promoting economic growth. The United States Government equates good governance with democracy and sees it as end in itself. The US Government has promised to link its foreign aid to the existence of democratic regimes abroad; it is required in law to cut off aid to regimes coming to power by overthrowing a democratically elected government; and it has begun to programme some of its aid to promote democracy abroad - for example, political party training and the financing of election observers.

Promoting democracy abroad is not a new policy for the United States. In a number of cases in the past, the US military imposed a democratic regime on occupied countries, not just the Philippines, Japan and Germany but also in a variety of countries in Central America. Supporting democracy abroad has been a recurrent theme in US policies since the Second World War, though more compelling security concerns, particularly resisting the expansion of Communist influence, frequently overrode those policies.

The end of the Cold War has eliminated the principal constraint on Washington's support for democracy

\footnotetext{
9 International Bank for Reconstruction and Development, Articles of Agreement, Article IV, Section 10.
} 
beyond US borders. It is no longer necessary to provide foreign aid to corrupt but diplomatically helpful autocrats. The US is free to extend its human rights policies, long popular with the American public, to political rights, linking the closeness of its relations to foreign governments to their performance in both areas. And this has now begun to happen, in words and actions. US aid has been cut to Mobutu Sese Seko of Zaire, one of the world's most corrupt leaders but one who has long been supportive of US interests in Africa. It has cut aid to Kenya pending political liberalization there. Four years ago, the US would not have taken such action, valuing access for its Air Force and Navy to air and port facilities in Mombasa should an emergency arise in the Indian Ocean or Persian Gulf.

But it is not just the end of the Cold War and the re-emergence of values as an influence in US aid policies that has given rise to the current emphasis in Washington on promoting democracy abroad. It is also a practical response to a variety of domestic political imperatives. The most urgent imperative is finding a rationale for a $\$ 15$ billion a year foreign aid programme.

The United States began to transfer concessional resources abroad in the late 1940s as an effort to bolster the governments and economies of Greece and Turkey in the face of a communist-led insurgency in the former country and Soviet pressures for territorial concessions from the latter country. The Marshall Plan soon followed aid to Greece and Turkey and was also motivated by a concern that lagging economic recovery in Western Europe would lead to an expansion of communist influence there. From the very beginning, US foreign aid has rested heavily on the need to respond to external threats to US and world security emanating from the Soviet Union. Indeed, it seems likely that without such threats, an insular American public and a sceptical Congress would have never acquiesced to a sizeable foreign aid programme in the years following the Second World War. Security concerns were the first and remained the principal pillar on which the US aid programme has rested over the past 45 years.

The second pillar is promoting development abroad. This goal gained prominence during the 1960 s and, though the definition of 'development' and understandings of how aid can best promote it have shifted almost on a decade by decade basis, the goal has remained important to the maintenance of the core constituency of political liberals in Congress who would support the annual passage of legislation appropriating aid monies.

Several changes over the past decade have eroded both of these pillars. In the early years of its aid programmes, US security concerns and development needs could be found in the same countries. East Asian countries, like Korea, and after the Cuban Revolution, Latin American countries, were areas of priority attention in Washington and were needy enough to justify concessional loans and grants for development. In the $1970 \mathrm{~s}$, Washington's attention shifted to Indochina, where aid could again be justified on both security and development grounds. During the 1980s, US security concerns in the developing world focused on Central America and the Middle East. But many of the countries in these regions were no longer among the world's poorest. Meanwhile, the most urgent development needs were in sub-Saharan Africa, where US security interests were minimal. Security and development needs had begun to diverge.

During the mid-1970s and 1980s, another element began to influence the size and direction of US aid -domestic political interests, above all, the pro-Israel lobby. Although large amounts of aid to Israel could not easily be justified on the basis of development needs, security concerns combined with pressures on Congress from lobbying groups ensured that a substantial proportion of US aid was directed towards Israel. There are many on Capitol Hill who credit the exceptionally effective pro-Israel lobby with the continuing increase in overall levels of US aid.

With the ending of the Cold War, the critical security rationale for aid is now gone, and the rationale for aid to Israel is also diminishing, as the country is no longer as threatened by regimes in Syria and Iraq backed by the USSR. Recent hardline policies by the Bush administration to resist increases in aid to Israel suggest that domestic political pressures are insufficient by themselves to ensure large US aid flows to that country (except during the election campaigns).

The second pillar on which US aid has rested promoting development abroad - is also much weakened, for two reasons. One is that, in the area of the developing world where aid flows from all sources have been largest in relation to recipient economies, sub-Saharan Africa, aid has proven ineffective in ensuring development. The economic problems in many parts of Africa appear to have worsened even as the size of aid inflows have grown. It is difficult to justify aid for development without definitive success stories to point to. As in the case of the World Bank, there appears to be a loss of confidence among Washington aid officials that they can achieve their mission, particularly in Africa.

But there is a more fundamental problem eating away at the development foundation of US aid. With the increasing geographic differentiation between US security concerns and development needs abroad, there has been a loss of interest at the most senior levels of the 
US government in promoting development abroad. This is not a phenomenon of the Bush administration alone. It can be traced back to the Nixon administration or before, and its manifestations include a lack of White House involvement in development issues or in lobbying Congress on aid, and the appointment of political cronies rather than individuals of national stature with an interest in development to head the Agency for International Development (AID). Most recently, it is reflected in the absence of any vision of how aid can be used to promote development on the part of administration officials. Rather, official statements on how US development aid is to be used have become a collection of fashionable clichés, of ten lacking in substance and with little coherence. For example, initiatives announced by AID in 1990 and 1991 have included a democracy programme, a partnership for business and development, a programme for family and development, an environment initiative, an effort to promote US exports and a strategic management programme.

What is happening here is a groping for a new set of rationales to justify the continuation of US aid abroad now that the security rationale is gone and the development rationale is much eroded. The emphasis on using aid to promote democracy is a manifestation of this groping, one that is based on 'core values' shared by the majority of Americans and their representatives in Congress and intended to provide them with a reason to support or at least acquiesce in the continuation of aid abroad.

Other factors have contributed to the emphasis in Washington on promoting democracy abroad. Conservatives in the US have complained that the administration has been more critical of the Republic of South Africa for the absence of full democracy there than it has been of other African governments. Part of the motivation of senior State Department officials in criticizing non-democratic black African regimes and offering aid to reward or to support democratization in Africa has been to ensure that their criticisms of South Africa appear balanced. The emphasis in Nicaragua was to encourage democratic elections on the assumption that the Sandinistas would lose, which they did.

The issues raised by the US government's emphasis on promoting democracy abroad are somewhat different from those raised by the Bretton Woods institutions' emphasis on good governance. First, the US has not yet set clear priorities on promoting democracy versus promoting development abroad. While there appears to be an inclination on the part of the Congress to assign top priority to democracy - through legislation to prohibit aid to regimes coming to power by overthrowing democratically elected governments - the administration has continued to provide aid to nondemocratic regimes, like that of Ghana, as long as they continue to implement structural adjustment programmes. Indeed, if the administration became too strict in its emphasis on democracy as a precondition for aid, it might find itself with a great deal of unspent aid monies on its hands, particularly in Africa where semi-democracies or regimes promising future elections are common.

A second problem for the US as well as other governments actively advocating political liberalization abroad is whether they are willing to take responsibility for the consequences. Governments, in contrast to multilateral institutions, are much better positioned to intervene where needed to smooth democratic transitions and help resolve conflicts between political groups where those conflicts threaten to become violent. But in the case of the United States, there appears to be little inclination to take on such responsibilities except in countries where significant US economic or domestic political interests are involved. At present, this excludes all of sub-Saharan Africa, except possibly the Republic of South Africa.

A third issue in promoting democracy abroad is how to use foreign aid effectively to accomplish this goal. There are essentially two approaches. One involves conditioning aid flows to political liberalization refusing to provide aid where authoritarian governments resist pressures to liberalize and providing aid to governments implementing political reforms. The second approach is to target aid on the political forces supporting liberalization and critical to its success, for example, political parties, the legislature, the judiciary, the press, and civic associations. Aid funds can provide training, financing, and technical assistance. However, aid for either of these purposes is a double edged sword; it can help but it can also hurt the implementation and consolidation of democracy. Too much aid, poorly timed, can undermine the incentives for governments to liberalize, particularly where internal pressures based on economic discontent are the prime force promoting political reform. Too much aid to finance new institutions - for example, legislatures or political parties - can undermine the independence of those institutions (particularly political parties and civic associations) and their incentives to create grass roots support needed to sustain them and ensure their sensitivity to those they are supposed to represent. Too much aid can encourage newly elected politicians to create political constituencies primarily on the basis of patronage, buying off political opposition and stifling national debate on policies and governance. Too much aid as a reward for political refor ms can also undermine incentives for new governments to implement economic reforms. How much aid is enough to promote democratization but not so much that it is stifled remains a very difficult issue. 


\section{CONCLUSION}

A new chapter appears to have commenced in aid and development relationships, one in which considerations of 'governance' promise to play an important role. Whether that role will be a constructive one, benefiting the mass of people in the developing world through improvements in their standard of living as well as their political rights, or whether it will lead to confusion and greater rather than less political turmoil, is still far from certain. Most important is that those governments and institutions proposing to take the lead in promoting better governance in other countries be clear about their goals, realistic about their capacities to achieve those (including whether they are in fact attainable) and accountable for their actions to their own publics and those in the countries whose environments they are attempting to shape. Much work remains to be done.

\section{REVIEW BOOKS RECEIVED}

The World Bank/United Nations Development Programme/Commission of the European Communities/Food and Agriculture Organization, 'Small-scale fisheries: research needs', World Bank Technical Paper 152, Fisheries Series, The Worid Bank, Washington DC, 1991

The European Journal of Development Research, Vol 3 No 2, December 1991

United Nations Development Programme, Human Development Report 1992, Oxford University Press, 1992

Monica S. Fong and Heli Perrett, Women and Credit: The Experience of Providing Financial Services to Rural Women in Developing Countries, Finafrica Foundation, Milan, 1992

R. E. Downs, Donna O. Kerner and Stephen P. Reyna (eds), The Political Economy of African Famine, (Food and Nutrition in History and Anthropology Volume 9), Gordon and Breach, Philadelphia, Reading, Paris, Montreux, Tokyo, Melboume, 1991

African Housing Fund: Community Builders Bulletin, No 2, 1991

Big Mistakes, Small Solutions: Technology and the Environment, Intermediate Technology Development Group, Rugby, 1992

The Ford Foundation Report, Vol 23 No 1, Spring 1992

Rajesh Chandra, Industrialization and Development in the Third World, Routledge, London, 1992

Korean Situation in 1991, Christian Institute for the Study of Justice and Development, Korea, 1992

Gioacchino Garofoli (ed.), Endogenous Development and Southem Europe, Avebury, Aldershot, 1992

Oxfam Review of Journals, No 34, January - April 1992 